\title{
M-Traveling: Mobile Applications in Tourism
}

\author{
André Constantino da Silva \\ Institute of Computing (PG) \\ UNICAMP IFSP
}

\author{
Heloísa Vieira da Rocha \\ Institute of Computing, NIED \\ UNICAMP
}

\begin{abstract}
The use of mobile devices has many purposes, including commerce, entertainment and education. Some of these applications deliver information about a city or region. Since these devices are portable and can deliver information where there is internet access, a new potential use is in travels. We call mtraveling. But which free applications are available to aim tourists? What features and problems these applications have? To answer these questions, this work presents four studies cases done in four cities for one tourist, using a total of 26 mobile applications. Analyzing the data collected in the studies cases is possible to highlight some important features and some problems in these applications.
\end{abstract}

\section{Introduction}

Many applications are available for mobile devices and can be categorized by its purpose as entertainment, social web access, wealth and matches information, education and communications. Some of them are developed to provide information about a city or region, like business centers, parks, restaurants and historic places. These applications are starting a new use of mobile devices, we call m-Traveling. m-Traveling can be define as the use of applications developed to mobile devices to aim a person or a group of person during a tour in some place.

Considering the scope of applications developed for provide information about a city or region, which kind applications are available? What are its main features and problems? To answer these questions, we performed four studies cases with one voluntary to use a smartphone during city tours. Three studies case was published in our previous work [1], and in these extend version we related a new study case and discussed more deeply these questions.

A total of 26 mobile applications are used, most of them are Location Based Services (LBS). LBS are information services accessible with mobile devices through the mobile network and utilizing the ability to make use of the location of the mobile device [2]. Steiniger et al. [3] says LBS applications can be characterized by a number of keyword: mobile users, mobile activities, information, search and spatial analysis, user interface, visualization and technology. Most of these characteristics can be applied to m-
Traveling app (application), so most of apps we consider at $\mathrm{m}$-Traveling category, can be consider as LBS too. But some others, like language learning apps, not have all LBS characteristics. Learning language applications do not necessarily needs search and spatial analysis, but can help users into a conversation in travels and we consider it as mTraveling application. In this paper, most of all analyzed applications are LBS too, due to the quantity of available LBS applications.

Session 2 describes the methods and material, and Session 3 describes the studies cases and the used applications. Session 4 summarize the features of these applications, divided into applications categories, and discuss some problems. Session 5 presents final considerations and future works.

\section{Methods and materials}

The exploratory study was adopted as method, and the following steps were suggested:

i) Downloading useful applications before the trip;

ii) Understand how to use the application;

iii) Use the downloaded applications in the trip;

iv) Write down the experience uses;

v) If needs, download more applications and use during the trip.

The participant of the studies cases is a mid-age man who speak Portuguese and English, never travel abroad, neither to the cities selected to run the studies cases: Lisbon, Valencia, Madrid and Barcelona. The participant does not speak Spanish or Catalan.

We used a Motorola Milestone smartphone [4], 3.7 inches multi-touch display with 133MB internal storage memory expansive up to 32 GB with a memory card, $600 \mathrm{MHz}$ Cortex-A8 processor and 256 MB RAM, a 5MP camera, GPS and wireless connection by Wi-Fi $802.11 \mathrm{~b} / \mathrm{g}$ and bluetooth. The battery used is a Li-Ion $1400 \mathrm{mAh}$ to support $6 \mathrm{~h}$ 30min talking time. Due to the smartphone use be intensive (screen, GPS and Wi-Fi components), the user carried with her an extra battery. No 3G connection was used.

Motorola Milestone has a proximity sensor, an ambient light sensor, a 3-axis accelerometer and a geomagnetism sensor to provide orientation with respect to Earth's magnetic field. The proximity sensor and the accelerometer can be used to interact 
with applications, but no one of the used applications take account this kind of interaction.

Android 2.1 [5] was used as Operation System (OS) in the first three studies cases described in this paper: Lisbon, Valencia and Madrid. For the last study case, Barcelona, the OS was Android 4.0.3.

To give preference in the use of mobile applications, the user was invited to do not use printed map, but carry one for use in the case of battery runs out, applications crashes or missing information. The user was allowed to choose transportation modality, but looking first into the applications before asking help for someone.

\section{Studies cases}

Four studies cases (SC) were done to explore mobile applications and its features. The first three studies cases, run out at February 2012, are described in our previous work [1] and the last one was run in September 2012.

The next sub-sessions explain each study case and the used applications. The cities visited were: Lisbon (SC1), Valencia (SC2), Madrid (SC3) and Barcelona (SC4).

Since the Lisbon, Valencia and Madrid were visited consecutively, the user prefers to create a panel for each city (Fig. 1), except for Valencia, the user create two panels due to the quantity of used applications and for easy launch. For Barcelona, the user created a panel (Fig. 2) to organize the icons, and this panel there was not related with the others panels (Fig. 1) due the reset mobile device in the SO update. Each panel has icon launch applications for the related city. The panels order showed in the Fig. 1 follows the order created by the user, who preferred to put panel for Lisbon (first visited city) next to panel with the power widget, to easy turn on/off devices features to save energy.

\subsection{Study Case 1: Lisbon}

A two days tour was made in Lisbon, Portugal, and a total of 5 applications were used: LisbonMap ViewTravel version 0.6.8 [6], Go2Gay version 2.10 [7], Google Maps version 6.3.0 [8], Footfeed version 1.1 [9], Facebook for Android version 1.8.3 [10].

LisbonMap ViewTravel [6] is a guide tour application with suggestions for restaurants, hotel, attractions, shopping, nightlife, tour and other places. Two features of this application are a subway map and offline streets map with marks indicating bus stops, tram stops and subway entrances. The user can mark the current position in the map, useful to save the accommodation localization.

Go2Gay [7] is an international guide used in studies cases 2 and 3 too, similar to LisbonMap but with GLS and friendly places. Go2Gay has two versions, a free one and a charge one, and we used the free version. The free version has access information about the venues, selecting venues by category, and allowing add new venues or report closed venue or incorrect information. The charge version has the possibility to read and write reviews by the application mobile. Go2Gay has a site too with the same data, but with all features.

Google Maps [8] was used to get directions and routes. One function used was mark the place of the accommodation with a star (favorite place). Google Maps have the feature to preload the map around the user and suggest route walking, driving car or using public transport. Another feature from Google Maps is the turn-by-turn navigation.

Footfeed [9] is an application to check-in to Foursquare [11], Gowalla [12], Google Latitude [13]

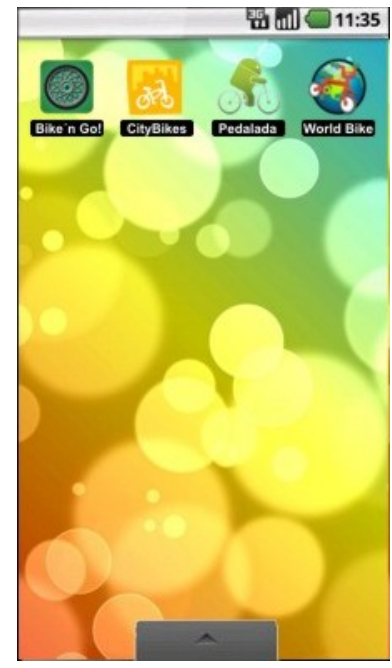

(a)

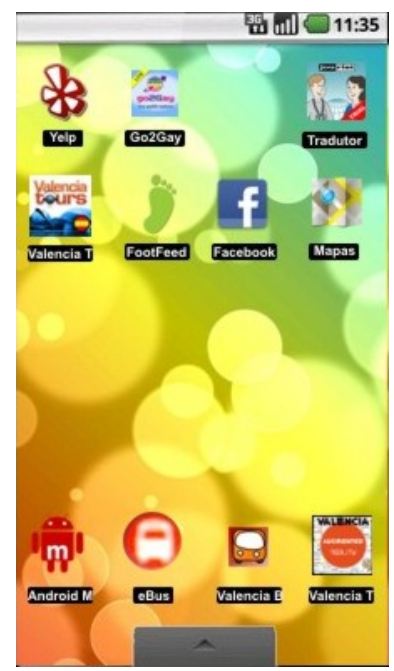

(b)

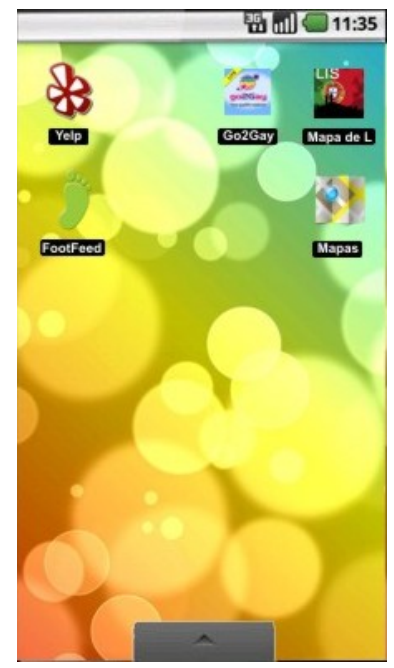

(c)

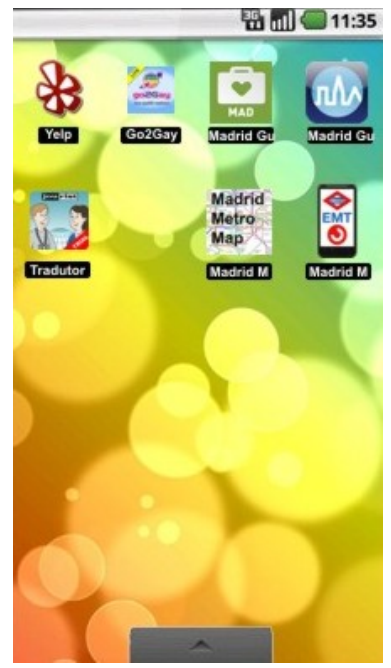

(d)

Figure 1. Four panels designed to easily access the applications (a) and (b) SC2 Valencia; (c) SC1 Lisbon (d) SC3 Madrid. 


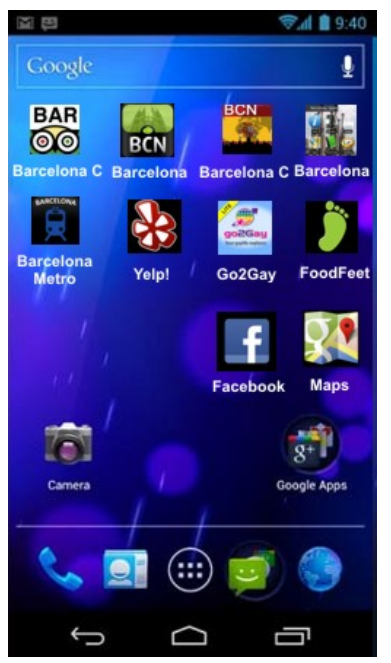

\section{Figure 2. Panel designed to easily access the applications in the SC4 Barcelona.}

and Facebook Places [14] and post to Twitter [15] and Facebook [16]. Facebook for Android [10] is an application to share information and photos with friends in Facebook [16].

Since the Portuguese are spoken in Portugal and Brazil, no applications about learning language were used. LisbonMap and Go2Gay were both used to find places to go. They have different audience, so the data contain in these applications are complementary. Go2Gay does not have information about public transportation, only business venues.

Google Maps was used to calculate routes, like route between the accommodation and the airport using public transportation. Google Maps allows changing the date and the time, so previous planning is possible. It is important to highlight Google Maps data are update to the Lisbon bus system, an important issue to this kind of application.

FootFeed and Facebook are both used to share information and photos about the visited places with user friends. Since the FootFeed is integrated with Google Latitude and Facebook, it is possible to track the travel.

\subsection{Study Case 2: Valencia}

A week tour was made in Valencia, Spain, and a total of 15 applications were used: Yelp version 2.9.4 [17], Valencia Tours version 1.6 [18], Android Metro Valencia version 1.4.8 [19], Valencia Tube Augment Reality version 2.0 [20], eBus EMT Valencia version 0.7 [21], Valencia Bus version 2 [22], Bikén Go! version 1.4 [23], CityBikes version 1.4.6 [24], Cycle Hire Widget Lite version 2.20 [25], World Bike version 2.4.1 [26], Travel Interpreter version 1.1 [27].

Yelp [17] is an application to suggest venues to go out like restaurants, attractions and other places.
This application allows user to write reviews about the venues, and have the same propose with LisbonMap. Valencia Tours [18] is a guide tour application with suggestions for tourist places, bars, shops and restaurants. It is offers four routes suggestions, a cultural agenda and audio description for touristic places.

Android Metro Valencia [19] is an application with information about the Valencia metro, aim to plain routes between metro stations. Valencia Tube Augment Reality [20] is an application to facilitate the use of Valencia Metro public transport. This application uses augment reality to show the nearest metro stop. eBus EMT Valencia [21] provides information about the Valencia buses. With the bus stop code, user can access the waiting time for the next bus. The application provides a map where the user can see all bus stops. Valencia Bus [22] is similar to eBus EMT Valencia, provides information about the buses, but does not provide a map with bus stops.

Bike'n Go! [23], CityBikes [24], Cycle Hire Widget Lite [25] and World Bike [26] has similar purpose: aim users to find bikes and stations in a bike rental. Bike'n Go! aims to find a bike rental station and provide the number of available bikes and slots at Valencia. Provide features to favorite stations, to find the nearest bike station, to see stations around and check account. CityBikes has information about many cities and provides a filter in circle format with radius adjust to search bike stations nearby the user. Cycle Hire Widget Lite shows the bike stations and distance and directions for each bike station. Cycle Wire Widget offers to a widget to easy see nearby stations and them directions. World Bike shows the bike stations into a map and the station status and offers an alarm that the voluntary uses to controls the bike using time and returns the bike before the free time finish.

Travel Interpreter [27] is a phrasebook with illustrations and audio description. The phrases are categorized to facilitate the search and have a search phrase mechanism. And more 4 applications: Go2Gay version 2.10 [7], Google Maps version 6.3.0 [8], Footfeed version 1.1 [9] and Facebook for Android version 1.8.3 [10], described into subsession 3.1.

Yelp and Go2Gay were used complementary to find a place to go, mainly shops, bars and restaurants. Valencia Tours was used to visit historical places, and learning about them listen the audio description. Android Metro Valencia, Valencia Tube Augment Reality, eBus EMT Valencia and Valencia Bus were used to get information about public transport. But the voluntary prefers uses bikes to locomotion, so the applications Bike'n Go!, CityBikes, cycle Hire Widget Lite and World Bike were most used. Travel Interpreter was used to learning some Spanish sentences, used to 
greeting, asking for something, for buy, ask the time and directions.

\subsection{Study Case 3: Madrid}

A five days tour was made in Madrid, Spain, and a total of 10 applications were used: Madrid Metro|Bus|Cercanias version 3.0.4 [28], Madrid Metro Map version madrid-metro-map [29], Madrid Travel Guide - Triposo Travel Guides (TTG) version 1.6 [30], Madrid Travel Guide - I Wanna Go There (IWGT) version 1.15 [31].

Madrid Metro|Bus|Cercanias [28] provides information about the Madrid public transport, schematic and geographic subway map, and waiting time into a bus stop and features to aim to calculate routes between metro stops and to find nearest metro station. Madrid Metro Map version madrid-metromap [29] provides a static schematic map for Madrid subway.

Madrid Travel Guide - Triposo Travel Guides (TTG) [30] is a guide tour application with suggestions for restaurants, hotel, attractions, shopping, nightlife, tour and other places. It is possible to see all registered venues and information about them in a map, and bookmark or check-in at interesting points. Madrid Travel Guide - I Wanna Go There (IWGT) [31] is a guide tour application with suggestions for things to do, travel tips, eating \& drinking places to stay and shopping. The application offers too tips about the city and neighborhoods. It is possible to see all registered venues and information about them in a map.

And more 6 applications: Travel Interpreter version 1.1 [27] and Yelp version 2.9.4 [17] (described into sub-session 2.2), Go2Gay version 2.10 [7], Google Maps version 6.3.0 [8], FootFeed version 1.1 [9] and Facebook for Android version 1.8.3 [10] (described into sub-session 3.1).

Madrid Metro|Bus|Cercanias and Madrid Metro Map were used to get information about metro. The user did not use bus in this study case, but some features were tested. Madrid Travel Guide TTG, IWGT and Go2Gay are used to find places to go out. The other applications were used as the same as the other studies cases.

\subsection{Study Case 4: Barcelona}

A week tour was made in Barcelona, Spain, at September 2012, and a total of 6 applications were used: Barcelona City Guide by TripAdvisor version 2.8 [32], Barcelona Travel Guide by PRS Marketing
Services SL version 1.6 [33], Barcelona Metro Map by iLicitMedia version 100.2 [34], Barcelona ViewTravel version 0.6.8 [35], Barcelona Travel Guide by EuroAsia Singapore version 1.1 [36] and Foursquare for Android version 2012.09.25 [11]. And more 4 applications: Go2Gay version 2.10 [7], Google Maps version 6.3.0 [8], Footfeed version 1.1 [9] and Facebook for Android version 1.8.3 [10], described into sub-session 3.1.

Barcelona City Guide by TripAdvisor [32], Barcelona Travel Guide by PRS Marketing Services SL [33], Barcelona ViewTravel [35] and Barcelona Travel Guide by EuroAsia Singapore [36] are all guide tours applications. Barcelona City Guide by TripAdvisor has information about restaurants, hotels, attractions like historical places and parks, suggestions for itineraries and Barcelona metro map. Barcelona Travel Guide by PRS Marketing Services [33] has information about the popular places in Barcelona, and the information about the places are writing by the users, so the main focus on this application is sharing experiences among the travelers.

Barcelona ViewTravel [35] is similar to Lisbon ViewTravel but with information about Barcelona. Barcelona ViewTravel has the subway map, offline streets map and suggestions for restaurants, hotel, attractions, shopping, nightlife, tour and other places.

Barcelona City Guide by TripAdvisor, Barcelona ViewTravel and Barcelona Travel Guide by EuroAsia Singapore allows downloading the data and access it on off-line mode.

Barcelona Travel Guide by EuroAsia Singapore [36] has information about the city and hotels and some photos of the popular venues.

Barcelona Metro Map [34] is an application with information about the Barcelona metro by a static image.

Foursquare for Android [11] was used to do check-ins in visited places and publish where the traveler was, but due the restriction of Internet access, few check-ins are done.

\section{Useful features and main problems}

Through this exploratory study we can compare applications by feature, highlight some useful issues and major problems of this kind of applications. But it is important categorize the used applications and compare them by features, so we divided the applications in the following categories: guide tour, bike rental, bus information, virtual map, social network and language learning. 
Table 1. Bike rental applications compare by features

\begin{tabular}{|c|c|c|c|c|}
\hline $\begin{array}{c}\text { Feature I } \\
\text { application }\end{array}$ & Bike’n Go! & CityBikes & $\begin{array}{l}\text { Cycle Hire Widget } \\
\text { Lite }\end{array}$ & World Bike \\
\hline $\begin{array}{l}\text { Visualization of bike } \\
\text { stations }\end{array}$ & Map (default), list & Map (default), list & List (default), map & List (default), map \\
\hline $\begin{array}{l}\text { Visualization of bike } \\
\text { stations status }\end{array}$ & $\begin{array}{l}\text { Colors in map, and } \\
\text { colors and numbers } \\
\text { at list }\end{array}$ & $\begin{array}{c}\text { Colors in map, and } \\
\text { colors and numbers } \\
\text { at list }\end{array}$ & $\begin{array}{l}\text { Colors in map, and } \\
\text { colors and numbers } \\
\text { at list }\end{array}$ & $\begin{array}{l}\text { Colors in map, and } \\
\text { numbers at list }\end{array}$ \\
\hline Rental instructions & no & no & no & no \\
\hline Show location & yes & yes & yes & yes \\
\hline Show orientation & yes (map view) & no & Yes (map view) & no \\
\hline Route & no & no & $\begin{array}{c}\text { Google Maps } \\
\text { integration }\end{array}$ & no \\
\hline $\begin{array}{l}\text { Search for near } \\
\text { stations }\end{array}$ & yes (map view) & yes (map view) & yes & List view \\
\hline Data refresh & Each 5 minutes & By user requesting & $\begin{array}{c}\text { Each } 20 \text { minutes, } \\
\text { on demand }^{\mathrm{a}}\end{array}$ & By user requesting \\
\hline Time tracking alarm & yes & no & no & yes \\
\hline $\begin{array}{c}\text { Favorite bike } \\
\text { stations }\end{array}$ & Yes & yes & yes $^{a}$ & yes \\
\hline Search station & yes & no & no & no \\
\hline $\begin{array}{c}\text { Account } \\
\text { visualization }\end{array}$ & yes & no & no & no \\
\hline Map Data & Google Maps & Google Maps & Google Maps & Google Maps \\
\hline Web Site & no & yes & no & No \\
\hline Reviews in Market ${ }^{b}$ & 1 & 43 & 330 & 2 \\
\hline $\begin{array}{l}\text { Ratings in Market } \\
\text { (stars numbers / } \\
\text { votes) }{ }^{b}\end{array}$ & $4.8 / 69$ & $4.1 / 311$ & $4.3 / 1,404$ & $3.4 / 26$ \\
\hline
\end{tabular}

b. Data collected in October/2012

Table 1 presents a comparative among Bike Rental applications considering available features considered useful for the user when she used these kind of application. All used apps uses maps and lists to visualize bike stations, and use colors and numbers to show available bikes. No one of the used apps have information about how to rent a bike, important information for the users. All tested apps show the user location on a map, but only Bike'n Go! and Cycle Hire Widget Lite show user orientation (where the user as facing at). And only the Cycle Hire Widget Lite does route. Another feature the user point at as important was time tracking alarm, used to alert the user when the time to use a bike for free is getting over. To see how much money the user has in her account, Bike'n Go! has the feature account visualization, the other applications does not have this feature.

Table 2 considers bus information applications. To analyze bus information apps, we considered information available like bus schedule, fees values, payment method and visualization of the bus stops, and features like search bus stop by bus code and for near bus stop. No one used application has information about fees values and payment methods and do not search for near bus stops given a bus line.

An identified problem is that most of the used applications are built for citizens, so tourists may have problems using them. For example, usually tourists does not know number or names of buses lines, so it is necessary to ask someone, because applications like Madrid Metro|Bus|Cercanias needs the bus code to show the bus schedule. A better alternative is asking the user about where (address or reference point or point at the map) she wants to go and calculate a route.

Table 3 considers subway information applications. Important information about subway system was subway map, account view, visualization subway entrances, fees values and metro opening hours. Features considered important were searching for subway station, find near subway entrance, and planning routes using metro. Most of the apps have subway schematic map, but not interactive: the user only see a picture and use zoom in and zoom out and navigation into the map. Most of the apps do not provide features to search for entrances given the name or the user localization. Madrid Metro|Bus |Cercanias and Android Metro Valencia have 
Table 2. Bus information applications compare by features

\begin{tabular}{|c|c|c|c|}
\hline $\begin{array}{c}\text { Feature I } \\
\text { applicatio } \\
\text { n }\end{array}$ & $\begin{array}{c}\text { Valencia } \\
\text { Bus }\end{array}$ & $\begin{array}{c}\text { eBus } \\
\text { EMT } \\
\text { Valencia }\end{array}$ & $\begin{array}{c}\text { Madrid } \\
\text { Metrol } \\
\text { Bus| } \\
\text { Cercania } \\
\text { s }\end{array}$ \\
\hline $\begin{array}{c}\text { Bus } \\
\text { schedule }\end{array}$ & no & no & yes \\
\hline $\begin{array}{c}\text { Fees } \\
\text { values }\end{array}$ & no & no & no \\
\hline $\begin{array}{l}\text { Payment } \\
\text { method }\end{array}$ & no & no & no \\
\hline $\begin{array}{l}\text { Search by } \\
\text { bus stop }\end{array}$ & $\begin{array}{l}\text { by bus } \\
\text { stop code }\end{array}$ & $\begin{array}{l}\text { by bus } \\
\text { stop code }\end{array}$ & $\begin{array}{l}\text { by bus } \\
\text { line code } \\
\text { or line } \\
\text { name }\end{array}$ \\
\hline $\begin{array}{l}\text { Account } \\
\text { view }\end{array}$ & yes & yes & no \\
\hline $\begin{array}{l}\text { Visualizati } \\
\text { on of bus } \\
\text { stops }\end{array}$ & no & map view & list \\
\hline $\begin{array}{l}\text { Search for } \\
\text { near bus } \\
\text { stop }\end{array}$ & no & no & no \\
\hline $\begin{array}{l}\text { Reviews } \\
\text { in Market }^{\mathrm{a}}\end{array}$ & 0 & 2 & 41 \\
\hline $\begin{array}{l}\text { Ratings in } \\
\text { Market } \\
\text { (stars } \\
\text { numbers / } \\
\text { votes) }^{a}\end{array}$ & $3.7 / 23$ & $4.3 / 186$ & $\begin{array}{r}4.5 / \\
3,175\end{array}$ \\
\hline
\end{tabular}

a. Data collected in October/2012

features to trace a route between stations. Only Madrid Metro|Bus |Cercanias app has information about fees values.

Table 4 presents a comparative among guide tour applications. Features considered important were city information, find a venue, visualize venues and their position, add venues, and report wrong information. Yelp, LisbonMap ViewTravel and Go2Gay only do searches when the user is connected on Internet, a problem when the user is without internet access.

Most of the used apps give information about touristic venues and provide their localization in a map. This map is resulted, in most of these applications, by an integration with Google Maps, allowing the user ask for routes. For venues have telephone number, the applications (like Madrid Travel Guide - TTG, Barcelona Guide TripAdvisor, Yelp) allows call to the venue touching in the telephone number.

One identified problem is the outdate information about the venues. Some of applications the user manage the information have wrong information, e.g., a business venue does not exist anymore, or wrong opening hour. Maybe the number of users is still small, or the update data is hard to do (for example the user needs to access the site to report).

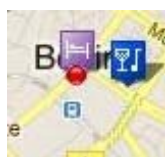

(a)

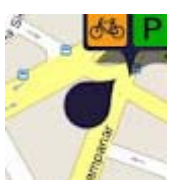

(b)

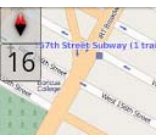

(c)
Figure 3. Interface components used to give users localizations or orientation: a) icon on map; b) marker where user is facing at; c) compass on map.

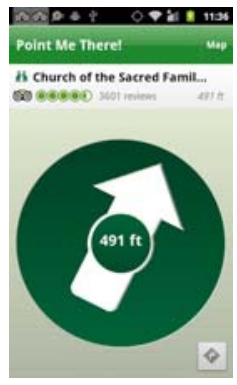

(a)

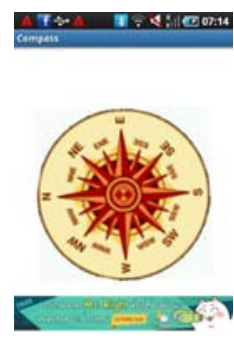

(b)

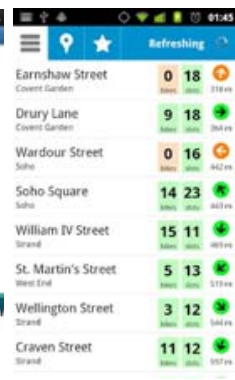

(c)
Figure 4. Compass designs used in the analyzed applications: a) entire screen pointing at a venue; b) entire screen pointing at north; c) a list of direction signals.

There is a lack of integration between the applications and all features provide by the mobile device. It is clear the use of Google Maps by Go2Gay to show the venues in a map, but into Go2Gay is not possible to use some Google Maps features, like direction and routes.

This kind of problem turn hard the task to get a route to go to a specific venue, because it is necessary to memorize the venue address, launch the Google Maps application, search the address and ask for a route.

Considering the device features, it is possible to see which application has used the feature and provide some important information, and describe how the user interface designers expose it. Table 5 and Table 6 show a compare among the applications by mobile feature.

The main uses of user global position are for point at the map the user localization, calculate route or calculate distance. Put the user localization in a map is a feature that frameworks for Android provide, so few effort of the developer is necessary to use this data. The sign used among the applications that draw the user localization at map is different. Almost of them uses only a point (Fig. 3a), but there are applications that uses the default Android sign to show the user orientation (geomagnetism orientation) or some sign similar that have a prickle to point where the user are faced to (Fig. 3b).

Geomagnetism orientation is also used to draw a compass, like in the World Bike app (shows a compass in the map, Fig. 3c) or in the entire screen, 
Table 3. Subway information applications compare by features

\begin{tabular}{|c|c|c|c|c|c|c|c|}
\hline $\begin{array}{l}\text { Feature I } \\
\text { applicati- } \\
\text { on }\end{array}$ & $\begin{array}{l}\text { Android } \\
\text { Metro } \\
\text { Valencia }\end{array}$ & $\begin{array}{l}\text { Valencia } \\
\text { Tube } \\
\text { Augment } \\
\text { Reality }\end{array}$ & $\begin{array}{l}\text { Madrid } \\
\text { Metro|Bus } \\
\text { |Cercanias }\end{array}$ & $\begin{array}{l}\text { Madrid } \\
\text { Metro Map }\end{array}$ & $\begin{array}{l}\text { Lisbon } \\
\text { Map }\end{array}$ & $\begin{array}{l}\text { Barcelona } \\
\text { Metro Map }\end{array}$ & $\begin{array}{l}\text { Barcelona } \\
\text { City Guide } \\
\text { TripAdvisor }\end{array}$ \\
\hline $\begin{array}{l}\text { Subway } \\
\text { map }\end{array}$ & Schematic & no & $\begin{array}{l}\text { Schematic, } \\
\text { geographic }\end{array}$ & Schematic & Schematic & Schematic & Schematic \\
\hline $\begin{array}{l}\text { Search for } \\
\text { subway } \\
\text { station }\end{array}$ & yes & Only a list & Only a list & no & no & no & yes \\
\hline $\begin{array}{l}\text { Account } \\
\text { view }\end{array}$ & no & no & no & no & no & no & no \\
\hline $\begin{array}{l}\text { Visualizati- } \\
\text { on of } \\
\text { subway } \\
\text { entrance }\end{array}$ & map view & $\begin{array}{l}\text { augment } \\
\text { reality view }\end{array}$ & no & no & no & no & No \\
\hline $\begin{array}{l}\text { Show } \\
\text { orientation }\end{array}$ & no & $\begin{array}{l}\text { Yes } \\
\text { (augment } \\
\text { reality } \\
\text { view) }\end{array}$ & no & no & no & no & no \\
\hline $\begin{array}{l}\text { Search for } \\
\text { near } \\
\text { entrance }\end{array}$ & yes & no & yes & no & no & no & No \\
\hline Route & $\begin{array}{l}\text { yes, only } \\
\text { between } \\
\text { stations }\end{array}$ & $\begin{array}{c}\text { yes, } \\
\text { integrated } \\
\text { with } \\
\text { Google } \\
\text { Maps } \\
\end{array}$ & $\begin{array}{c}\text { only } \\
\text { between } \\
\text { stations }\end{array}$ & no & no & no & no \\
\hline $\begin{array}{l}\text { Offline } \\
\text { data }\end{array}$ & $\begin{array}{l}\text { Subway } \\
\text { map only }\end{array}$ & yes & $\begin{array}{c}\text { Subway } \\
\text { map }\end{array}$ & $\begin{array}{c}\text { Subway } \\
\text { map }\end{array}$ & $\begin{array}{c}\text { Subway } \\
\text { map }\end{array}$ & yes & yes \\
\hline $\begin{array}{l}\text { Fees } \\
\text { values }\end{array}$ & no & no & yes & no & no & no & no \\
\hline $\begin{array}{l}\text { Metro } \\
\text { opening } \\
\text { hours } \\
\text { information }\end{array}$ & no & no & yes & no & no & no & no \\
\hline $\begin{array}{l}\text { Reviews in } \\
\text { Market }^{\mathrm{a}}\end{array}$ & 1 & 0 & 41 & 7 & 1 & 0 & 187 \\
\hline $\begin{array}{l}\text { Ratings in } \\
\text { Market } \\
\text { (stars } \\
\text { numbers / } \\
\text { votes) }^{a}\end{array}$ & 3.9 / 69 & $4.2 / 10$ & $4.5 / 3,175$ & $3.8 / 74$ & $2.6 / 10$ & $5.0 / 9$ & $4.7 / 1,030$ \\
\hline
\end{tabular}

a. Data collected in October/2012

like in Barcelona City Guide by TripAdvisor (Fig. 4a). Barcelona City Guide by TripAdivsor provides orientation through a compass in entire screen point out a venue, but not in the map. So turns hard to user figure out other interesting venues. The Barcelona Trip Guide by EuroAsia Singapore app gives the user a compass, but point at north (Fig. 4b), different from Barcelona City Guide by TripAdivsor that the arrow points at the chosen venue. Pointing to the avenue is better in the task to go to a venue because gives orientation to the user.

The geomagnetism orientation can be used not only for one venue, but for many, like City Hire
Widget does (Fig. 4c). This use is good when the users have many chooses and can decide where to go. But the arrow weight can prejudice the user, for example, when you are biking it is more easy choose one venue to go and follow the direction (showed in an entire screen compass) than always looking for the desirable arrow in a list.

Multitouch gestures are few used. Most are used on map interaction to zoom in, zoom out or map navigation. Since the almost applications are integrated with Google maps, there is no effort to developers codifying this feature. The same happens 
Table 4. Guide tour applications comparative by features

\begin{tabular}{|c|c|c|c|c|c|c|}
\hline $\begin{array}{c}\text { Featurel } \\
\text { application }\end{array}$ & $\begin{array}{l}\text { Valencia } \\
\text { tours }\end{array}$ & Yelp & $\begin{array}{l}\text { LisbonMap } \\
\text { ViewTravel }\end{array}$ & Go2Gay & $\begin{array}{l}\text { Madrid } \\
\text { Travel } \\
\text { Guide - } \\
\text { IWGT }\end{array}$ & $\begin{array}{c}\text { Madrid } \\
\text { Travel } \\
\text { Guide - TTG }\end{array}$ \\
\hline $\begin{array}{l}\text { City } \\
\text { information }\end{array}$ & yes & no & no & $\begin{array}{l}\text { no (only in } \\
\text { site) }\end{array}$ & yes & yes \\
\hline $\begin{array}{l}\text { Search } \\
\text { venue } \\
\text { restrictions }\end{array}$ & no & Only online & Only online & Only online & no & no \\
\hline $\begin{array}{l}\text { Search } \\
\text { method }\end{array}$ & no & $\begin{array}{c}\text { By } \\
\text { categories } \\
\text { and words }\end{array}$ & $\begin{array}{l}\text { By categories } \\
\text { and criteria }\end{array}$ & $\begin{array}{c}\text { By } \\
\text { categories } \\
\text { only }\end{array}$ & $\begin{array}{c}\text { By } \\
\text { categories } \\
\text { only }\end{array}$ & $\begin{array}{c}\text { By } \\
\text { categories } \\
\text { and words }\end{array}$ \\
\hline $\begin{array}{l}\text { Search result } \\
\text { visualization }\end{array}$ & no & $\begin{array}{l}\text { List (default), } \\
\text { map }\end{array}$ & List & $\begin{array}{c}\text { Map } \\
\text { (default), list }\end{array}$ & $\begin{array}{l}\text { List (default), } \\
\text { map }\end{array}$ & List \\
\hline Add venue & no & yes & $\begin{array}{l}\text { yes (in map } \\
\text { view) }\end{array}$ & yes & no & no \\
\hline $\begin{array}{l}\text { Revise } \\
\text { venue } \\
\text { information }\end{array}$ & no & yes & $\begin{array}{c}\text { yes (in map } \\
\text { view) }\end{array}$ & yes & no & $\begin{array}{l}\text { yes (when } \\
\text { there is a } \\
\text { lack of } \\
\text { information) }\end{array}$ \\
\hline $\begin{array}{l}\text { touristic } \\
\text { places marks } \\
\text { in the map }\end{array}$ & yes & yes & yes & no & yes & yes \\
\hline $\begin{array}{l}\text { Touristic } \\
\text { places } \\
\text { suggestions }\end{array}$ & yes & yes & no & no & yes & yes \\
\hline $\begin{array}{l}\text { Favorite } \\
\text { venues/ } \\
\text { bookmarks }\end{array}$ & no & yes & yes & no & no & yes \\
\hline $\begin{array}{l}\text { Search } \\
\text { history }\end{array}$ & no & no & yes & no & no & no \\
\hline $\begin{array}{l}\text { Venue } \\
\text { localization } \\
\text { on map view }\end{array}$ & no & yes & yes & yes & yes & yes \\
\hline $\begin{array}{l}\text { Route for a } \\
\text { venue }\end{array}$ & $\begin{array}{l}\text { Yes, integrated } \\
\text { with Google } \\
\text { Maps (needs } \\
\text { connection) }\end{array}$ & $\begin{array}{l}\text { Yes, integrated } \\
\text { with Google } \\
\text { Maps (needs } \\
\text { connection) }\end{array}$ & $\begin{array}{l}\text { By bike, by car } \\
\text { and walking } \\
\text { with audio } \\
\text { output } \\
\text { directions }\end{array}$ & yes & $\begin{array}{l}\text { Yes, integrated } \\
\text { with Google } \\
\text { Maps (needs } \\
\text { connection) }\end{array}$ & no \\
\hline Call venue & yes & yes & yes & yes & no & yes \\
\hline $\begin{array}{l}\text { Read/write } \\
\text { ratings }\end{array}$ & no & yes & Only read & yes & Only read & no \\
\hline $\begin{array}{l}\text { Read/write } \\
\text { reviews }\end{array}$ & no & yes & Only read & yes & Only read & no \\
\hline $\begin{array}{l}\text { Touristic } \\
\text { Information }\end{array}$ & yes & no & no & no & yes & Yes \\
\hline $\begin{array}{l}\text { Site } \\
\text { integration }\end{array}$ & no & $\begin{array}{c}\text { Yes, unless } \\
\text { monocle } \\
\text { feature }\end{array}$ & $\begin{array}{l}\text { With same } \\
\text { features }\end{array}$ & $\begin{array}{l}\text { With same } \\
\text { features }\end{array}$ & $\begin{array}{c}\text { Yes, site has } \\
\text { more } \\
\text { features }\end{array}$ & no \\
\hline Offline data & yes & no & $\begin{array}{c}\text { Street and } \\
\text { subway } \\
\text { maps }\end{array}$ & no & yes & yes \\
\hline $\begin{array}{l}\text { Social web } \\
\text { characteristics }\end{array}$ & no & yes & no & no & no & no \\
\hline $\begin{array}{l}\text { Sharing } \\
\text { location }\end{array}$ & no & yes & $\begin{array}{c}\text { Using } \\
\text { smartphone } \\
\text { features }\end{array}$ & $\begin{array}{c}\text { Using } \\
\text { smartphone } \\
\text { features }\end{array}$ & no & $\begin{array}{c}\text { With } \\
\text { Facebook }\end{array}$ \\
\hline $\begin{array}{l}\text { Reviews in } \\
\text { Market }^{\mathrm{a}}\end{array}$ & 2 & 480 & 1 & 11 & 1 & 2 \\
\hline $\begin{array}{lr}\text { Ratings } & \text { in } \\
\text { Market (stars } \\
\text { numbers } \\
\text { votes) }^{\mathrm{a}}\end{array}$ & $4.2 / 56$ & $4.3 / 6,515$ & $2.6 / 10$ & $2.5 / 42$ & $4.1 / 16$ & 3.9 / 35 \\
\hline
\end{tabular}


Table 4. Guide tour applications comparative by features (cont.)

\begin{tabular}{|c|c|c|c|c|c|}
\hline $\begin{array}{c}\text { Featurel } \\
\text { application }\end{array}$ & $\begin{array}{l}\text { Madrid Travel } \\
\text { Guide - TTG }\end{array}$ & $\begin{array}{c}\text { Barcelona City } \\
\text { Guide - } \\
\text { TripAdvisor }\end{array}$ & $\begin{array}{c}\text { Barcelona City } \\
\text { Guide } \\
\text { TravelView }\end{array}$ & $\begin{array}{c}\text { Barcelona } \\
\text { Travel Guide - } \\
\text { PRS Marketing }\end{array}$ & $\begin{array}{c}\text { Barcelona Trip } \\
\text { Guide - } \\
\text { EuroAsia } \\
\text { Singapore } \\
\end{array}$ \\
\hline City information & yes & yes & No & Yes & Yes \\
\hline $\begin{array}{l}\text { Search venue } \\
\text { restrictions }\end{array}$ & no & No & Only online & No & $\begin{array}{l}\text { Yes (Google } \\
\text { maps) }\end{array}$ \\
\hline Search method & $\begin{array}{l}\text { By categories } \\
\text { and words }\end{array}$ & $\begin{array}{l}\text { By categories } \\
\text { and words }\end{array}$ & $\begin{array}{l}\text { By categories } \\
\text { and criteria }\end{array}$ & $\begin{array}{l}\text { By categories } \\
\text { and words }\end{array}$ & No \\
\hline $\begin{array}{l}\text { Search result } \\
\text { visualization }\end{array}$ & List & $\begin{array}{l}\text { List (default), } \\
\text { map }\end{array}$ & List & List & No \\
\hline Add venue & no & No & $\begin{array}{l}\text { yes (in map } \\
\text { view) }\end{array}$ & No & No \\
\hline $\begin{array}{l}\text { Revise venue } \\
\text { information }\end{array}$ & $\begin{array}{l}\text { yes (when there } \\
\text { is a lack of } \\
\text { information) }\end{array}$ & No & $\begin{array}{l}\text { yes (in map } \\
\text { view) }\end{array}$ & No & No \\
\hline $\begin{array}{l}\text { touristic places } \\
\text { marks in the } \\
\text { map }\end{array}$ & yes & Yes & yes & Yes & No \\
\hline $\begin{array}{l}\text { Touristic places } \\
\text { suggestions }\end{array}$ & yes & Yes & no & Yes & Yes \\
\hline $\begin{array}{l}\text { Favorite } \\
\text { venues/ } \\
\text { bookmarks }\end{array}$ & yes & yes & yes & Yes & No \\
\hline Search history & no & No & yes & No & No \\
\hline $\begin{array}{l}\text { Venue } \\
\text { localization on } \\
\text { map view }\end{array}$ & yes & yes & yes & Yes & No \\
\hline $\begin{array}{l}\text { Route for a } \\
\text { venue }\end{array}$ & no & $\begin{array}{l}\text { No (but point at } \\
\text { m gives } \\
\text { direction) }\end{array}$ & $\begin{array}{l}\text { By bike, by car } \\
\text { and walking } \\
\text { with audio } \\
\text { output } \\
\text { directions } \\
\end{array}$ & Yes & No \\
\hline Call venue & yes & yes & yes & Yes & No \\
\hline $\begin{array}{l}\text { Read/write } \\
\text { ratings }\end{array}$ & no & Yes & Only read & No & No \\
\hline $\begin{array}{l}\text { Read/write } \\
\text { reviews }\end{array}$ & no & Yes & Only read & Yes (on site) & No \\
\hline $\begin{array}{l}\text { Touristic } \\
\text { Information }\end{array}$ & Yes & Yes & no & Yes & Yes \\
\hline Site integration & no & Yes & $\begin{array}{c}\text { With same } \\
\text { features }\end{array}$ & Yes & No \\
\hline Offline data & yes & Yes & $\begin{array}{c}\text { Street and } \\
\text { subway maps }\end{array}$ & Yes & Yes \\
\hline $\begin{array}{l}\text { Social web } \\
\text { characteristics }\end{array}$ & no & no & no & Yes & No \\
\hline $\begin{array}{l}\text { Sharing } \\
\text { location }\end{array}$ & With Facebook & no & $\begin{array}{c}\text { Using } \\
\text { smartphone } \\
\text { features }\end{array}$ & no & no \\
\hline $\begin{array}{l}\text { Reviews in } \\
\text { Market }^{\mathrm{a}}\end{array}$ & 1 & 187 & 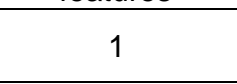 & 1 & 0 \\
\hline $\begin{array}{lr}\text { Ratings } & \text { in } \\
\text { Market } & \text { (stars } \\
\text { numbers } & / \\
\text { votes) }^{a} & \\
\end{array}$ & $4.1 / 16$ & $4.7 / 1,030$ & $2.4 / 14$ & $3.5 / 39$ & $4.7 / 7$ \\
\hline
\end{tabular}


Table 5. Applications compare by mobile features-localization and geomagnetism orientation

\begin{tabular}{|c|c|c|}
\hline $\begin{array}{c}\text { Application IMobile } \\
\text { Feature }\end{array}$ & Localization & Geomagnetism orientation \\
\hline Bike'n Go! & $\begin{array}{c}\text { Icon on map, } \\
\text { Organize points of interest by distance }\end{array}$ & Marker where user is facing at \\
\hline CityBikes & $\begin{array}{c}\text { Icon on map, } \\
\text { Calculate distance between user and a point } \\
\text { of interest and walking time, } \\
\text { Organize points of interest by distance }\end{array}$ & no \\
\hline Cycle Hire Widget Lite & $\begin{array}{c}\text { Icon on map, } \\
\begin{array}{c}\text { Calculate distance between user and a point } \\
\text { of interest }\end{array} \\
\end{array}$ & $\begin{array}{l}\text { Direction signals to station (list } \\
\text { station) compass (map view) }\end{array}$ \\
\hline World Bike & Icon on map & Compass (map view) \\
\hline Valencia Bus & no & no \\
\hline Ebus EMT Valencia & no & no \\
\hline $\begin{array}{l}\text { Madrid Metro| } \\
\text { Bus|Cercanias }\end{array}$ & $\begin{array}{c}\text { Calculate distance between user and a point } \\
\text { of interest and walking time, } \\
\text { Organize points of interest by distance }\end{array}$ & Compass (map view) \\
\hline $\begin{array}{l}\text { Android Metro } \\
\text { Valencia }\end{array}$ & $\begin{array}{c}\text { Choose nearest subway } \\
\text { Calculate walking time to a point of interest }\end{array}$ & no \\
\hline $\begin{array}{l}\text { Valencia Tube } \\
\text { Augment Reality }\end{array}$ & $\begin{array}{c}\text { Icon on map, } \\
\text { Calculate distance between user and a point } \\
\text { of interest, } \\
\text { Organize points of interest by distance }\end{array}$ & Display points, and a radar \\
\hline Madrid Metro Map & No & no \\
\hline $\begin{array}{l}\text { Lisbon MapView } \\
\text { Travel }\end{array}$ & $\begin{array}{c}\text { Icon on map, } \\
\text { Calculate distance between user and a point } \\
\text { of interest }\end{array}$ & compass (map view) \\
\hline Yelp & $\begin{array}{c}\text { Icon on map, } \\
\text { Calculate distance between user and a point } \\
\text { of interest } d \text { walking time, } \\
\text { Organize points of interest by distance }\end{array}$ & Display points \\
\hline Go2Gay & Icon on map & no \\
\hline $\begin{array}{l}\text { Madrid Travel Guide - } \\
\text { IWGT }\end{array}$ & $\begin{array}{c}\text { Calculate distance between user and a point } \\
\text { of interest }\end{array}$ & no \\
\hline $\begin{array}{l}\text { Madrid Travel Guide - } \\
\text { TTG }\end{array}$ & $\begin{array}{c}\text { Icon on map, } \\
\text { Organize points of interest by distance }\end{array}$ & no \\
\hline $\begin{array}{l}\text { Barcelona City Guide } \\
\text { by TripAdvisor }\end{array}$ & $\begin{array}{c}\text { Icon on map, } \\
\text { Calculate distance between user and a point } \\
\text { of interest }\end{array}$ & Marker where user is facing at \\
\hline $\begin{array}{l}\text { Barcelona City Guide } \\
\text { TravelView }\end{array}$ & $\begin{array}{c}\text { Icon on map, } \\
\text { Calculate distance between user and a point } \\
\text { of interest }\end{array}$ & Compass (map view) \\
\hline $\begin{array}{l}\text { Barcelona Travel } \\
\text { Guide - PRS } \\
\text { marketing }\end{array}$ & 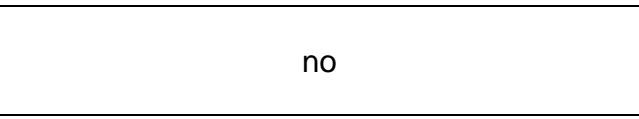 & no \\
\hline $\begin{array}{l}\text { Barcelona Trip Guide } \\
\text { - EuroAsia Singapore }\end{array}$ & no & no \\
\hline Barcelona Metro Map & no & no \\
\hline Valencia Tours & $\begin{array}{c}\text { Calculate distance between user and a point } \\
\text { of interest, } \\
\text { Organize points of interest by distance }\end{array}$ & no \\
\hline
\end{tabular}

when the applications show a bitmap picture (schematic or geographic), multitouch gesture to zoom and navigate in a image are default in Android platform.

\section{Final considerations}

Mobile devices are been used with different purposes, e.g. entertainment, news, commerce and communication. There are applications offers information about public transportations, language, bar and restaurants, museums and others venues that can be used by travelers. We call this as mTraveling, it consists of development and use of mobile applications to aim a person or a group of people during a tour in some place. 
Table 6. Applications compare by mobile features - camera, multitouch gestures, vibration and sound

\begin{tabular}{|c|c|c|c|c|}
\hline $\begin{array}{c}\text { Application } \\
\text { IMobile Feature }\end{array}$ & $\begin{array}{l}\text { Camera (photo } \\
\text { and vídeo) }\end{array}$ & Multitouch Gestures & Vibration & Sound \\
\hline Bike'n Go! & son & $\begin{array}{c}\text { Map zoom and } \\
\text { navigation }\end{array}$ & Alarm time out & alarm \\
\hline CityBikes & no & $\begin{array}{l}\text { Map zoom and } \\
\text { navigation }\end{array}$ & no & no \\
\hline $\begin{array}{l}\text { Cycle Hire Widget } \\
\text { Lite }\end{array}$ & no & $\begin{array}{c}\text { Map zoom and } \\
\text { navigation }\end{array}$ & no & no \\
\hline World Bike & no & $\begin{array}{l}\text { Map zoom and } \\
\text { navigation }\end{array}$ & no & no \\
\hline Valencia Bus & no & no & no & no \\
\hline $\begin{array}{c}\text { Ebus EMT } \\
\text { Valencia }\end{array}$ & no & $\begin{array}{l}\text { Map zoom and } \\
\text { navigation }\end{array}$ & no & no \\
\hline $\begin{array}{l}\text { Madrid Metro| } \\
\text { Bus|Cercanias }\end{array}$ & no & $\begin{array}{c}\text { Map zoom and } \\
\text { navigation }\end{array}$ & no & no \\
\hline $\begin{array}{l}\text { Android Metro } \\
\text { Valencia }\end{array}$ & no & $\begin{array}{l}\text { Map zoom and } \\
\text { navigation }\end{array}$ & no & no \\
\hline $\begin{array}{c}\text { Valencia Tube } \\
\text { Augment Reality }\end{array}$ & Augment reality & $\begin{array}{c}\text { Map zoom and } \\
\text { navigation }\end{array}$ & no & no \\
\hline Madrid Metro Map & no & $\begin{array}{c}\text { Map zoom and } \\
\text { navigation }\end{array}$ & no & no \\
\hline $\begin{array}{c}\text { Lisbon MapView } \\
\text { Travel }\end{array}$ & no & $\begin{array}{c}\text { Map zoom and } \\
\text { navigation }\end{array}$ & no & no \\
\hline Yelp & $\begin{array}{l}\text { Augment reality } \\
\text { (monocle feature) }\end{array}$ & $\begin{array}{l}\text { Map zoom and } \\
\text { navigation }\end{array}$ & no & no \\
\hline Go2Gay & no & $\begin{array}{l}\text { Map zoom and } \\
\text { navigation }\end{array}$ & no & no \\
\hline $\begin{array}{l}\text { Madrid Travel } \\
\text { Guide - IWGT }\end{array}$ & no & $\begin{array}{c}\text { Map zoom and } \\
\text { navigation }\end{array}$ & no & no \\
\hline $\begin{array}{l}\text { Madrid Travel } \\
\text { Guide - TTG }\end{array}$ & no & $\begin{array}{l}\text { Map zoom and } \\
\text { navigation }\end{array}$ & no & No \\
\hline $\begin{array}{l}\text { Barcelona City } \\
\text { Guide by } \\
\text { TripAdvisor }\end{array}$ & no & $\begin{array}{l}\text { Map zoom and } \\
\text { navigation }\end{array}$ & no & no \\
\hline $\begin{array}{ll}\text { Barcelona City } \\
\text { Guide TravelView }\end{array}$ & no & $\begin{array}{c}\text { Map zoom and } \\
\text { navigation }\end{array}$ & no & no \\
\hline $\begin{array}{lr}\text { Barcelona } & \text { Travel } \\
\text { Guide - } & \text { PRS } \\
\text { marketing } & \\
\end{array}$ & no & $\begin{array}{l}\text { Map zoom and } \\
\text { navigation }\end{array}$ & no & no \\
\hline $\begin{array}{l}\text { Barcelona Trip } \\
\text { Guide - EuroAsia } \\
\text { Singapore }\end{array}$ & no & $\begin{array}{l}\text { Map zoom and } \\
\text { navigation }\end{array}$ & no & no \\
\hline $\begin{array}{ll}\text { Barcelona } & \text { Metro } \\
\text { Map } & \\
\end{array}$ & no & $\begin{array}{c}\text { Map zoom and } \\
\text { navigation }\end{array}$ & no & no \\
\hline Valencia Tours & no & no & no & yes (audio guide) \\
\hline
\end{tabular}

To study the support of available applications, we done four studies cases using a smartphone and applications during a trip. A total of 26 applications are used in this exploratory study. We faced with many problems; some are related with hardware and wireless connection, for example battery load and no internet access. Many of the used applications do not have an offline option, so they always need an internet access to work.

Other problems are related with software, like some crashes and usability problems. We agree usability is a key requirement to m-traveling applications, the information needs to be delivery in a proper form, considering efficient, efficacy and user satisfaction. Another problem is the lake of integration among devices applications, and between the device application and the Web application.

Through these studies cases, we perceive that the applications need to be improved to aim better travelers. Since most of the available applications are developed to be used to citizens, there is a clearly necessity of applications to use these data and presents for these users. There is too a necessity to design and evaluate methods for this kind of applications, and better exploit the resources offered by mobile devices. 


\section{Acknowledgements}

The authors thank the CAPES and CNPq for financial support and FAPESP through TIDIA-Ae Project (n. 05/60572-1), which provided the equipment.

\section{References}

[1] da Silva, A. C. and da Rocha, H. V. (2012) 'mTraveling: Experiences using mobile applications in tourism', in Proceedings of the International Conference on Information Society (i-Society 2012), IEEE Computer society Press: New York, USA. p. 26-31.

[2] K. Virrantaus, J. Markkula, A. Garmash and Y. V. Terziyan, 'Developing GIS-Supported Location-Based Services', Proceedings of WGIS'2001 - First International Workshop on Web Geographical Information Systems, Kyoto, Japan, pp. 423-432, 2001.

[3] S. Steiniger, M. Neun and A. Edwardes. 'Foundations of Location Based Services. Lesson 1', CartouCHe Lecture Notes on LBS, V 1.0. University of Zurich. http://www.e-cartouche.ch/content_reg/cartouche/LBSbasi $\mathrm{cs} / \mathrm{en} / \mathrm{html} /$ index.html (Access date: 02 Oct, 2012)

[4] Motorola Mobility Inc., 'Milestone Android - Phone Without Compromise - Tech Specs - Motorola Mobility India',http://www.motorola.com/Consumers/IN-EN/Consu mer-Products-and-Services/MobilePhones/ci.Motorola-MI LESTONE-IN-EN.alt (Access date: 02 Oct, 2012)

[5] Google. ‘Android', http://www.android.com/ (Access date: 02 Oct, 2012)

[6] Zhihong, L. 'Lisbon Map', http://play.google.com/st ore/apps/details?id=com.lisbon.mobson.view (Access date: 02 Oct, 2012)

[7] Go2 Websolutions BV. 'Go2Gay', http://play.google.c om/store/apps/details?id=com.g2glite (Access date: 02 Oct, 2012)

[8] Google Inc. ‘Google Maps', http://play.google.com/sto re/apps/details?id=com.google.android.apps.maps (Access date: 02 Oct, 2012)

[9] FootFeed. 'FootFeed', http://play.google.com/store/app s/details?id=com.footfeed (Access date: 02 Oct, 2012)

[10] Facebook@ $\odot$. 'Facebook for Android', http://play.goo gle.com/store/apps/details?id=com.facebook.katana (Access date: 02 Oct, 2012)

[11] Foursquare ${ }^{\circ}$. 'Foursquare', http://www.foursquare .com (Access Date: 02 Oct, 2012)

[12] Gowalla Inc. 'Gowalla', http://www.gowalla.com (Access date: 02 Oct, 2012)

[13] Google Inc. 'Google Latitude', http://www.google .com/latitude (Access Date: 02 Oct, 2012)

[14] Facebook@. 'Facebook Places', http://www.facebook .com/ about/location (Access Date: 02 Oct, 2012)
[15] Twitter@). 'Twitter', http://www.twitter.com (Access date: 02 Oct, 2012)

[16] Facebook@). 'Facebook', http://www.facebook.com (Access date: 02 Oct, 2012)

[17] Yelp. 'Yelp', http://play.google.com/store/apps/details ?id=com.yelp.android (Access date: 02 Oct, 2012)

[18] AudioTours-Turisapps. 'Valencia Tours', http://play .google.com/store/apps/details?id=valencia.tours.spanish (Access date: 02 Oct, 2012)

[19] D4 Mobiles. 'Android Metro Valencia', http://play .google.com/store/apps/details?id=com.metrovlcads.main (Access date: 02 Oct, 2012)

[20] Geomobile. 'Valencia Tube Augment Reality', http:// play.google.com/store/apps/details?id=com.geomobile.met rovalencia (Access date: 02 Oct, 2012)

[21] [zako]. 'eBus EMT Valencia’ http://play.google.com/ store/apps/details?id=es. zako.ebus (Access date: 02 Oct, 2012)

[22] Cowders. 'Valencia Bus’, http://play.google.com/store /apps/details?id=com.cowders.vlcbus (Access date: 02 Oct, 2012)

[23] SoftMyWay. 'Bikén Go', http://play.google.com/sto re/apps/details?id=com.softmyway. .android.bikengo

(Access date: 02 Oct, 2012)

[24] Awesome Enterprises. 'CityBik.es: Bike Sharing Networks Around the World', http://www.citybik.es/ (Access date: 02 Oct, 2012)

[25] Little Fluffy Toys Ltd. 'Cycle Hire Widget Lite', http://play.google.com/store/apps/details?id=com.littlefluff ytoys.cyclehire (Access date: 02 Oct, 2012)

[26] Sousa, M. 'World Bike', http://play.google.com/sto re/apps/details?id=com.marcomsousa.bicing (Access date: 02 Oct, 2012)

[27] Jourist Verlags GmbH. 'Travel Interpreter', http://play .google.com/store/apps/details?id=info.jourist.TravelInterp reterDemo (Access date: 02 Oct, 2012)

[28] Greenlion Soft. 'Madrid Metro|Bus|Cercanias', http:// play.google.com/store/apps/details?id=com.metrodroid.fre e.madrid (Access date: 02 Oct, 2012)

[29] Ray, B. 'Madrid Metro Map’, http://play.google.com /store/apps/details?id=madrid.subway.map (Access date: 02 Oct, 2012)

[30] Triposo Travel Guides. 'Madrid Travel Guide Triposo Travel Guides', http://play.google.com/store/apps /details?id=com.triposo.droidguide.madrid (Access date: 02 Oct, 2012)

[31] I Wanna Go There. 'Madrid Travel Guide - I Wanna Go There' http://play.google.com/store/apps/details?id=es. dm.iwannagothere.madrid (Access date: 02 Oct, 2012) 
[32] TripAdvisor. 'Barcelona City Guide’. http://play.goog le.com/store/apps/details?id=com.tripadvisor.android.apps. cityguide.barcelona (Access date: 02 Oct, 2012)

[33] PRS Marketing Services SL. 'Barcelona - Travel Guide’. http://play.google.com/store/apps/details?id=com. guides.minube.barcelona (Access date: 02 Oct, 2012)

[34] iLicitMedia. 'Barcelona Metro Map' http://play.googl e.com/store/apps/details?id=com.ilicit.barcelona.metro.hd (Access date: 02 Oct, 2012)

[35] Zhihong, L. 'Barcelona Map’. http://play.google.com /store/apps/details?id=com.barcelona.mobson.view (Access date: 02 Oct, 2012)

[36] EuroAsia Singapore. 'Barcelona Travel Guide'. http:// play.google.com/store/apps/details?id=com.euroasia.barcel ona (Access date: 02 Oct, 2012) 